\title{
DNA CLEAVAGE AND ANTIMICROBIAL ACTIVITY STUDIES ON TRANSITION METAL(II) COMPLEXES OF 4-AMINOANTIPYRINE DERIVATIVE
}

\author{
N.RAMAN*, S.THALAMUTHU, J.DHAVEETHU RAJA, M.A.NEELAKANDAN ${ }^{1}$ AND SHARMILA BANERJEE ${ }^{2}$
}

\author{
Research Department of Chemistry, VHNSN College, Virudhunagar-626 001, India \\ ${ }^{1}$ Department of Chemistry, National Engineering College, Kovilpatti-628 503, India \\ ${ }^{2}$ Baba Atomic Research Centre, Trombay, Mumbai-400 085, India \\ (Received: 18 May 2007 - Accepted: 18 January 2008)
}

\begin{abstract}
A new series of transition metal complexes of $\mathrm{Cu}(\mathrm{II}), \mathrm{Ni}(\mathrm{II}), \mathrm{Co}(\mathrm{II})$ and $\mathrm{Zn}$ (II) have been synthesized from the Schiff base (L) derived from 4-aminoantipyrine, salicylaldehyde and $o$-phenylenediamine. The structural features have been arrived from their elemental analyses, magnetic susceptibility, molar conductivity, FAB-mass, IR, UV-Vis., ${ }^{1} \mathrm{H}$ NMR and ESR spectral studies. The data show that the complexes have composition of ML type. The UV-Vis., magnetic susceptibility and ESR spectral data of the complexes suggest a square-planar geometry around the central metal ion. The antimicrobial activities of the metal chelates against the bacteria Salmonella typhi, Pseudomonas aeruginosa, Bacillus subtilis, Escherichia coli and fungi Aspergillus niger, Aspergillus flavus and Rhizoctonia bataicola have been carried out. A comparative study of MIC values of the Schiff base and its metal complexes indicates that the metal complexes exhibit higher antibacterial activity than the free ligand. The nuclease activity of the above metal complexes shows only the copper complex cleaves DNA.
\end{abstract}

Keywords: Schiff base, 4-aminoantipyrine, CT-DNA, nuclease activity

\section{INTRODUCTION}

Deoxyribonucleic acid (DNA) is the primary target molecule for most anticancer and antiviral therapies according to cell biology. Investigations of the interaction of DNA with small molecules are basic work in the design of new types of pharmaceutical molecules. Since the chemical nuclease activity of the copper-phenanthroline complex was discovered in $1980 \mathrm{~s},{ }^{1-3}$ studying the interaction model and the mechanism of transition metal complexes with DNA, and exploring the application of metal complexes in antineoplastic medication, molecular biology and bioengineering were hotspots in recent year. When some kinds of metal complexes interacted with DNA, they could induce the breakage of DNA strands by appropriate methods. Thus, after the double DNA strands are broken, the replication ability of cancer gene is destroyed. The interactions of metal complexes with DNA constitute a significant area of research which has attracted considerable attention from both inorganic chemists and biochemists because studies have shown that they are related to the development of new DNA reagents for biotechnology and medicine ${ }^{4,5}$. In recent years, binding studies of transition metal complexes have become very important in the development of DNA molecules probes and chemotherapeutics ${ }^{6-8}$. The characteristics common to these complexes are that the molecules have a high affinity for double stranded DNA and they bind a redox metal ion cofactor.

The interaction of metal complexes with DNA are well documented. The studies show that these molecules can interact in a non-covalent fashion with DNA by intercalation, groove-face finding or external electrostatic interaction. The changes in the intensities of electronic spectra can be used to explain the nature and strength of the stacking interactions between chromophores and DNA base pairs.

In recent years a considerable amount of work has been done on the coordination chemistry of copper(II) complexes with Schiff base ligands to model the physical and chemical behaviour of biological copper systems. Schiff bases of 4-aminoantipyrine and its complexes have a variety of application in biological, clinical, analytical and pharmacological areas ${ }^{9,10}$. Studies of new kinds of chemotherapeutic Schiff bases are now attracting the attention of biochemists ${ }^{11,12}$. Earlier work reported that some drugs showed increased activity, when administered as metal complexes rather than as organic compounds ${ }^{12,13}$. The coordinating properties of 4-aminoantipyrine have been modified to give a flexible ligand system, formed by condensation with a variety of reagents like aldehydes, ketones, thiosemicarbazides and carbazides etc $^{13-17}$. A literature search reveals that much work has been done on the transition metal complexes of 4-aminoantipyrine derivatives, but less has been carried out on the chemistry of transition metal complexes and biological behaviour involving the amino group of 4-aminoantipyrine. It is found that no work has been carried out on the synthesis of Schiff base and its transition metal complexes involving the carbonyl group of 4-aminoantipyrine. Hence, as part of our continuing efforts to synthesize and characterize simple Schiff base transition metal complexes ${ }^{17}$, in this paper we describe the synthesis, characterization, antimicrobial and DNA cleavage studies of transition metal complexes containing tetradentate Schiff base derived from salicylidene-4aminoantipyrine and $o$-phenylenediamine.

\section{EXPERIMENTAL}

Materials and Methods

All reagents were of Merck products and used as supplied. Anhydrous grade methanol and DMSO were obtained from Fisher Scientific Company. Microanalytical data and FAB Mass spectra of the compounds were recorded at the Regional Sophisticated Instrumentation Center, Central Drug Research Institute (RSIC, CDRI), Lucknow. The FAB mass spectrum of the complex was recorded on a JEOL SX 102/DA-6000 mass spectrometer/data system using argon/xenon $(6 \mathrm{kV}, 10 \mathrm{~mA})$ as the FAB gas. The accelerating voltage was $10 \mathrm{kV}$ and the spectra were recorded at room temperature using $\mathrm{m}$ nitrobenzylalcohol (NBA) as the matrix. The IR spectra of the samples were recorded on a Perkin-Elmer 783 spectrophotometer in 4000-200 $\mathrm{cm}^{-1}$ range using $\mathrm{KBr}$ pellet. The UV-Vis. spectra were recorded on a Shimadzu UV-1601 spectrophotometer using DMSO as solvent in the wave range of $200-800 \mathrm{~nm}$. The X-band ESR spectra of the complexes were recorded at 300 and $77 \mathrm{~K}$ at IIT, Mumbai using TCNE (tetracyanoethylene) as the g-marker. Magnetic susceptibility measurements of the complexes were carried out by Guoy balance using copper sulphate as the calibrant. The molar conductivity was measured with a Systronic conductivity bridge, using the freshly prepared solution of the complex in DMSO solution. Solutions of CT-DNA in $50 \mathrm{mmol}$ $\mathrm{NaCl} / 5 \mathrm{mmol}$ tris- $\mathrm{HCl}(\mathrm{pH}=7.0)$ gave a ratio of UV absorbance at 260 and $280 \mathrm{~nm}, \mathrm{~A}_{260} / \mathrm{A}_{280}$ of $c a .1 .8-1.9$, indicating that the DNA was sufficiently free of protein contamination. The DNA concentration was determined by the UV absorbance at $260 \mathrm{~nm}$ after 1:100 dilutions. Stock solutions were kept at $4^{\circ} \mathrm{C}$ and doubly distilled $\mathrm{H}_{2} \mathrm{O}$ was used to prepare the buffer.

Synthesis of Schiff base (L)

An ethanolic solution $(20 \mathrm{~mL})$ of 1-phenyl-2,3-dimethyl-4-aminopyrazol5-one $(2.03 \mathrm{~g}, 0.01 \mathrm{~mol})$ (4-aminoantipyrine) was added to an ethanolic solution of salicylaldehyde $(1.06 \mathrm{~g}, 0.01 \mathrm{~mol})$. On stirring the yellow coloured solid (I) was separated. It was filtered and recrystallised from ethanol. The solid (I) (3.074 g, $0.01 \mathrm{~mol})$ was added to an ethanolic solution $(20 \mathrm{~mL})$ of $o$ phenylenediamine $(0.541 \mathrm{~g}, 0.005 \mathrm{~mol})$. The mixture was refluxed for ca $30 \mathrm{~h}$. The brown solid (L) product was separated. It was filtered and recrystallised from ethanol (Fig. 1). Yield: $74 \%$; m.p: $200{ }^{\circ} \mathrm{C}$; Anal. calcd. for $\mathrm{C}_{42} \mathrm{H}_{38} \mathrm{~N}_{8} \mathrm{O}_{2}$ : C, 73.2; H, 5.5; N, 16.3; Found: C, 73.2; H, 5.4; N, 16.1 .

\section{Synthesis of complexes}

\section{Copper complex synthesis}

The Schiff base L $(0.6868 \mathrm{~g}, 0.001 \mathrm{~mol})$ dissolved in hot ethanol $\mathrm{mL})$ was added to a hot ethanolic solution $(25 \mathrm{~mL})$ of the $\mathrm{CuCl}_{2}(0.17 \mathrm{~g}, 0.001$ mol) and refluxed for $c a 4 \mathrm{~h}$. The resulting solution was reduced to one third on a water bath. The solid product separated was filtered and washed with hot ethanol. Yield: $56 \%$; m.p: $285^{\circ} \mathrm{C}$; Anal. calcd. for $\mathrm{CuC}_{42} \mathrm{H}_{38} \mathrm{~N}_{8} \mathrm{O}_{2} \mathrm{Cl}_{2}: \mathrm{Cu}, 7.7$; C, 61.4; H, 4.6; N, 13.6; Found: Cu, 8.9; C, 61.3; H, 4.2; N, 13.2. 

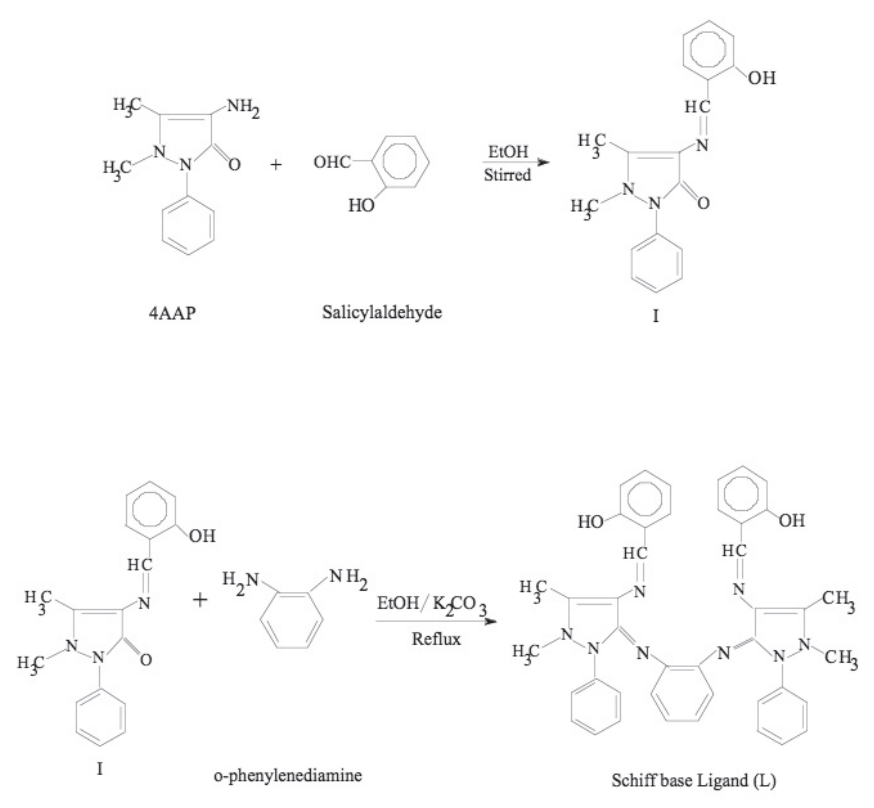

Figure 1. Formation of Schiff Base Ligand (L)

\section{Nickel complex synthesis}

The Schiff base L $(0.6868 \mathrm{~g}, 0.001 \mathrm{~mol})$ dissolved in hot ethanol $(50 \mathrm{~mL})$ was added to a hot ethanolic solution $(25 \mathrm{~mL})$ of the $\mathrm{NiCl}_{2}(0.23 \mathrm{~g}, 0.001 \mathrm{~mol})$ and refluxed for $c a 4 \mathrm{~h}$. The resulting solution was reduced to one third on a water bath. The solid product separated was filtered and washed with hot ethanol. Yield: $62 \%$; m.p: $254{ }^{\circ} \mathrm{C}$; Anal. calcd. for $\mathrm{NiC}_{42} \mathrm{H}_{38} \mathrm{~N}_{8} \mathrm{O}_{2} \mathrm{Cl}_{2}: \mathrm{Ni}, 7.2$; C, 61.8; H, 4.7; N, 13.7; Found: Ni, 7.0; C, 61.4; H, 4.6; N, 13.6.

\section{Cobalt complex synthesis}

The Schiff base L $(0.6868 \mathrm{~g}, 0.001 \mathrm{~mol})$ dissolved in hot ethanol $(50 \mathrm{~mL})$ was added to a hot ethanolic solution $(25 \mathrm{~mL})$ of the $\mathrm{CoCl}_{2}(0.23 \mathrm{~g}, 0.001 \mathrm{~mol})$ and refluxed for $c a 4 \mathrm{~h}$. The resulting solution was reduced to one third on a water bath. The solid product separated was filtered and washed with hot ethanol. Yield: $52 \%$; m.p: $269^{\circ} \mathrm{C}$; Anal. calcd. for $\mathrm{CoC}_{42} \mathrm{H}_{38} \mathrm{~N}_{8} \mathrm{O}_{2} \mathrm{Cl}_{2}$ : Co, 7.2; C, 61.8; H, 4.7; N, 13.7; Found: Co, 6.9; C, 61.5; H, 4.3; N, 13.1 .

\section{Zinc complex synthesis}

The Schiff base L $(0.6868 \mathrm{~g}, 0.001 \mathrm{~mol})$ dissolved in hot ethanol $(50 \mathrm{~mL})$ was added to a hot ethanolic solution $(25 \mathrm{~mL})$ of the $\mathrm{ZnCl}_{2}(0.13 \mathrm{~g}, 0.001 \mathrm{~mol})$ and refluxed for $c a 4 \mathrm{~h}$. The resulting solution was reduced to one third on a water bath. The solid product separated was filtered and washed with hot ethanol. Yield: $42 \%$; m.p: $246{ }^{\circ} \mathrm{C}$; Anal. calcd. for $\mathrm{ZnC}_{42} \mathrm{H}_{38} \mathrm{~N}_{8} \mathrm{O}_{2} \mathrm{Cl}_{2}: \mathrm{Zn}, 7.9$; C, 61.3; H, 4.6; N, 13.6; Found: Zn, 7.6; C, 60.9; H, 4.5; N, 13.5.

\section{Antimicrobial activity}

The in vitro antimicrobial screening effects of the investigated compounds were tested against the bacteria: Salmonella typhi, Staphylococcus aureus, Escherichia coli, and Bacillus subtilis by the well diffusion method, using agar nutrient as the medium. The antifungal activities of the compounds were evaluated by the well diffusion method against the fungi viz., Aspergillus niger, Aspergillus flavus and Rhizoctonia bataicola cultured on potato dextrose agar as medium. The stock solution $(0.01 \mathrm{~mol})$ was prepared by dissolving the compounds in DMSO and the solutions were serially diluted in order to find the MIC values. In a typical procedure a well was made on the agar medium inoculated with microorganisms. The well was filled with the test solution using a micropipette and the plate was incubated, $24 \mathrm{~h}$ for bacteria and $72 \mathrm{~h}$ for fungi at $35^{\circ} \mathrm{C}$. During this period, the test solution diffused and the growth of the inoculated microorganisms was affected. The inhibition zone was developed, at which the concentration was noted.

\section{Gel electrophoresis}

The gel electrophoresis experiments were performed by incubation at $35^{\circ} \mathrm{C}$ for $2 \mathrm{~h}$ as follows: CT DNA $30 \mu \mathrm{mol}, 50 \mu \mathrm{mol}$ each complex, $50 \mu \mathrm{mol} \mathrm{H} \mathrm{H}_{2}$ in $0.05 \mathrm{~mol}$ tris- $\mathrm{HCl}$ buffer $(\mathrm{pH}=7.2)$. The samples were electrophoresed for 2 $\mathrm{h}$ at $50 \mathrm{~V}$ on $1 \%$ agarose gel using tris-acetic acid-EDTA buffer, $\mathrm{pH}=8.3$. After electrophoresis, the gel was stained using $1 \mu \mathrm{g} / \mathrm{cm}^{3}$ ethidiumbromide (EB) and photographed under UV light.

\section{RESULTS AND DISCUSSION}

The analytical data for the ligand and complexes together with some physical properties are summarized in (Table 1). The analytical data of the complexes correspond well with the general formula $\mathrm{MLCl}_{2}$, where $\mathrm{M}=$ $\mathrm{Cu}(\mathrm{II}), \mathrm{Ni}(\mathrm{II}), \mathrm{Co}(\mathrm{II})$ and $\mathrm{Zn}(\mathrm{II}) ; \mathrm{L}=\mathrm{C}_{42} \mathrm{H}_{38} \mathrm{~N}_{8} \mathrm{O}_{2}$. The magnetic susceptibilities of the complexes at room temperature are consistent with square-planar geometry around the central metal ion. The higher conductance values of the chelates support their electrolytic nature of the metal complexes.

Table 1. Molar conductance and magnetic susceptibility data of the ligand and its complexes

\begin{tabular}{|c|c|c|c|c|}
\hline Compound & Molecular formula & Colour & $\begin{array}{c}\text { Molar } \\
\text { Conductance } \\
\Lambda \mathrm{m} \\
\left(\mathrm{mho} \mathrm{cm}^{2}\right. \\
\text { mol-1 }\end{array}$ & $\begin{array}{c}\text { Mag. } \\
\text { Moment } \\
\mu \text { eff } \\
\text { (B.M.) }\end{array}$ \\
\hline $\mathrm{L}$ & $\mathrm{C}_{42} \mathrm{H}_{38} \mathrm{~N}_{8} \mathrm{O}_{2}$ & Brown & ----- & ----- \\
\hline$[\mathrm{CuL}] \mathrm{Cl}_{2}$ & {$\left[\mathrm{CuC}_{42} \mathrm{H}_{38} \mathrm{~N}_{8} \mathrm{O}_{2}\right] \mathrm{Cl}_{2}$} & Black & 125 & 1.78 \\
\hline$[\mathrm{CoL}] \mathrm{Cl}{ }_{2}$ & {$\left[\mathrm{CoC}_{42} \mathrm{H}_{38} \mathrm{~N}_{8} \mathrm{O}_{2}\right] \mathrm{Cl}_{2}$} & Red & 127 & 3.48 \\
\hline$[\mathrm{NiL}] \mathrm{Cl} l_{2}$ & {$\left[\mathrm{NiC}_{42} \mathrm{H}_{38} \mathrm{~N}_{8} \mathrm{O}_{2}\right] \mathrm{Cl}_{2}$} & Green & 130 & ----- \\
\hline$[\mathrm{ZnL}] \mathrm{Cl}{ }_{2}$ & {$\left[\mathrm{ZnC}_{42} \mathrm{H}_{38} \mathrm{~N}_{8} \mathrm{O}_{2}\right] \mathrm{Cl}_{2}$} & $\begin{array}{c}\text { Pale } \\
\text { Brown }\end{array}$ & 142 & ---- \\
\hline
\end{tabular}

$\mathrm{L}=$ Ligand

\section{Mass spectra}

The FAB mass spectra of the ligand and its copper complex were recorded and compared for their stoichiometry compositions. The molecular ion peak for the ligand is observed at $686 \mathrm{~m} / \mathrm{z}$ ratio which is also supported by the "Nitrogen Rule", since the compound possesses the even number of nitrogen atoms. The molecular ion peak for the copper complex was observed at $\mathrm{m} / \mathrm{z}=821$, which confirms the stoichiometry of metal chelates as $\mathrm{MLCl}_{2}$ type. It is also supported by the FAB mass spectra of other complexes. Microanalytical data are also in close agreement with the values calculated from molecular formula assigned to these complexes, which is further supported by the FAB-mass studies of representative complexes.

\section{IR spectra}

The IR spectra provide valuable information regarding the nature of the functional group attached to the metal ion. The IR spectrum of the ligand shows a broad band in the region $3200-3600 \mathrm{~cm}^{-1}$, assignable to intramolecular hydrogen bonded $-\mathrm{OH}$ groups. The appearance of this peak in all the spectra of the complexes indicate that the $-\mathrm{OH}$ group is free from the complexation. The spectrum of the ligand shows two different $-\mathrm{C}=\mathrm{N}$ bands in the region $1625-1680 \mathrm{~cm}^{-1}$, which are shifted to lower frequencies in the spectra of all the complexes (1590-1650 $\left.\mathrm{cm}^{-1}\right)$ indicating the involvement of $-\mathrm{C}=\mathrm{N}$ nitrogen in coordination to the metal ion ${ }^{18,19}$. Accordingly, the ligand acts as a tetradentate chelating agent, bonded to the metal ion via the four nitrogen $(-\mathrm{C}=\mathrm{N})$ atoms of the Schiff base. Assignment of the proposed coordination sites is further supported by the appearance of medium bands at $450-400 \mathrm{~cm}^{-1}$ which could be attributed to $\mathrm{v}_{\mathrm{M}-\mathrm{N}}^{20,21}$.

\section{${ }^{1}$ H NMR}

The ${ }^{1} \mathrm{H}$ NMR spectrum of ligand (L) in $\mathrm{CDCl}_{3}$ gives the following signals: phenyl as multiplet at $7.2-7.6 \mathrm{ppm},=\mathrm{C}-\mathrm{CH}_{3}$ at $2.4 \mathrm{ppm},-\mathrm{N}-\mathrm{CH}_{3}$ at $3.2 \mathrm{ppm}$ and $-\mathrm{CH}=\mathrm{N}-$ protons at $9.8 \mathrm{ppm}$. The peak at $13.2 \mathrm{ppm}$ is attributable to the phenolic $-\mathrm{OH}$ group present in the salicylaldehyde. The presence of this peak noted for the zinc complex confirms the $-\mathrm{OH}$ proton free from complexation. The azomethine proton signal in the spectrum of the zinc complex is shifted 
downfield compared to the free ligand, suggesting deshielding of the azomethine group due to the coordination with metal ion. There is no appreciable change in all of the other signals of this complex.

\section{Electronic absorption spectra}

The electronic absorption spectra were recorded at $300 \mathrm{~K}$. The absorption region, assigned and the proposed geometry of the complexes are given in (Table 2). Based on these data, a square-planar geometry has been assigned to the complexes. These values are comparable with that of the other reported complexes $^{22-25}$. The observed zero magnetic moment confirms the square-planar environment for the nickel(II) complex in conformity with the fact that all known square-planar complexes of nickel(II) are diamagnetic. No transitions were observed in the visible region for $\mathrm{Zn}(\mathrm{II})$ complex consistent with the $\mathrm{d}^{10}$ configuration of the $\mathrm{Zn}$ (II) ion. This complex is also found to be diamagnetic as expected for $\mathrm{d}^{10}$ configuration.

Table 2. Electronic absorption spectral data of the compounds

\begin{tabular}{|c|c|c|c|c|}
\hline Compound & Solvent & $\begin{array}{l}\text { Absorption } \\
\left(\mathrm{cm}^{-1}\right)\end{array}$ & $\begin{array}{c}\text { Band } \\
\text { Assignment }\end{array}$ & Geometry \\
\hline L & DMSO & $\begin{array}{l}27100 \\
28818\end{array}$ & $\begin{array}{l}\text { INCT } \\
\text { INCT }\end{array}$ & ---- \\
\hline$[\mathrm{CuL}] \mathrm{Cl}_{2}$ & DMSO & $\begin{array}{l}28685 \\
30456 \\
23529\end{array}$ & $\begin{array}{c}\text { INCT } \\
\text { INCT } \\
{ }^{2} \mathrm{~B}_{1} \mathrm{~g} \rightarrow{ }^{2} \mathrm{~A}_{1} \mathrm{~g}\end{array}$ & $\begin{array}{l}\text { Square- } \\
\text { planar }\end{array}$ \\
\hline$[\mathrm{CoL}] \mathrm{Cl}_{2}$ & DMSO & $\begin{array}{l}28510 \\
30765 \\
21786\end{array}$ & $\begin{array}{c}\text { INCT } \\
\text { INCT } \\
{ }^{1} \mathrm{~A}_{1} \mathrm{~g} \rightarrow{ }^{1} \mathrm{~B}_{1} \mathrm{~g}\end{array}$ & $\begin{array}{l}\text { Square- } \\
\text { planar }\end{array}$ \\
\hline$[\mathrm{NiL}] \mathrm{Cl}_{2}$ & DMSO & $\begin{array}{l}27188 \\
30152 \\
15818 \\
19607\end{array}$ & $\begin{array}{c}\text { INCT } \\
\text { INCT } \\
{ }^{1} \mathrm{~A}_{1} \mathrm{~g} \rightarrow{ }^{1} \mathrm{~A}_{2} \mathrm{~g} \\
{ }^{1} \mathrm{~A}_{1} \mathrm{~g} \rightarrow{ }^{1} \mathrm{~B}_{1} \mathrm{~g}\end{array}$ & $\begin{array}{l}\text { Square- } \\
\text { planar }\end{array}$ \\
\hline
\end{tabular}

\section{ESR}

The ESR spectra of the copper complex, recorded in DMSO solution at $300 \mathrm{~K}$ and $77 \mathrm{~K}$ are shown in Figs. 2(a) and 2(b). The frozen solution spectrum shows a well resolved four line spectrum and no features characteristic for a dinuclear complex. This is also supported by the magnetic moment of copper complex (1.73B.M.) which confirms the mononuclear nature of the complex. The spin Hamiltonian parameters have been calculated for the copper complex from the spectra. The $g$ tensor values of this copper(II) complex can be used to derive the ground state. In scruare-planar complexes, the unpaired electron lies in the $\mathrm{d}_{\mathrm{x}}^{2}{ }^{2}$ orbital oiving $g_{\mathrm{p}}>\mathrm{g}_{\mathrm{p}}>2$ while the unpaired electron lies in the $\mathrm{d}^{2}$ orbital giving $g_{\perp}>g_{\mathrm{P}}>2$. r rum the observed values, it is clear that $g_{\mathrm{P}}\left(2.16^{2}\right)$ $>\mathrm{g}_{\perp}(2.03)>2$ whicn suggests that the complex is square-planar. Furtner, this is also supported by the fact that the unpaired electron lies predominantly in the $\mathrm{d}_{\mathrm{x}-\mathrm{y}}^{2}{ }^{2}$ orbital ${ }^{26-29}$, as was evident from the value of the exchange interaction term $\mathrm{G}$, estimated from the expression:

$$
G=\frac{g_{\mathrm{P}}-2.0023}{g_{\perp}-2.0023}
$$
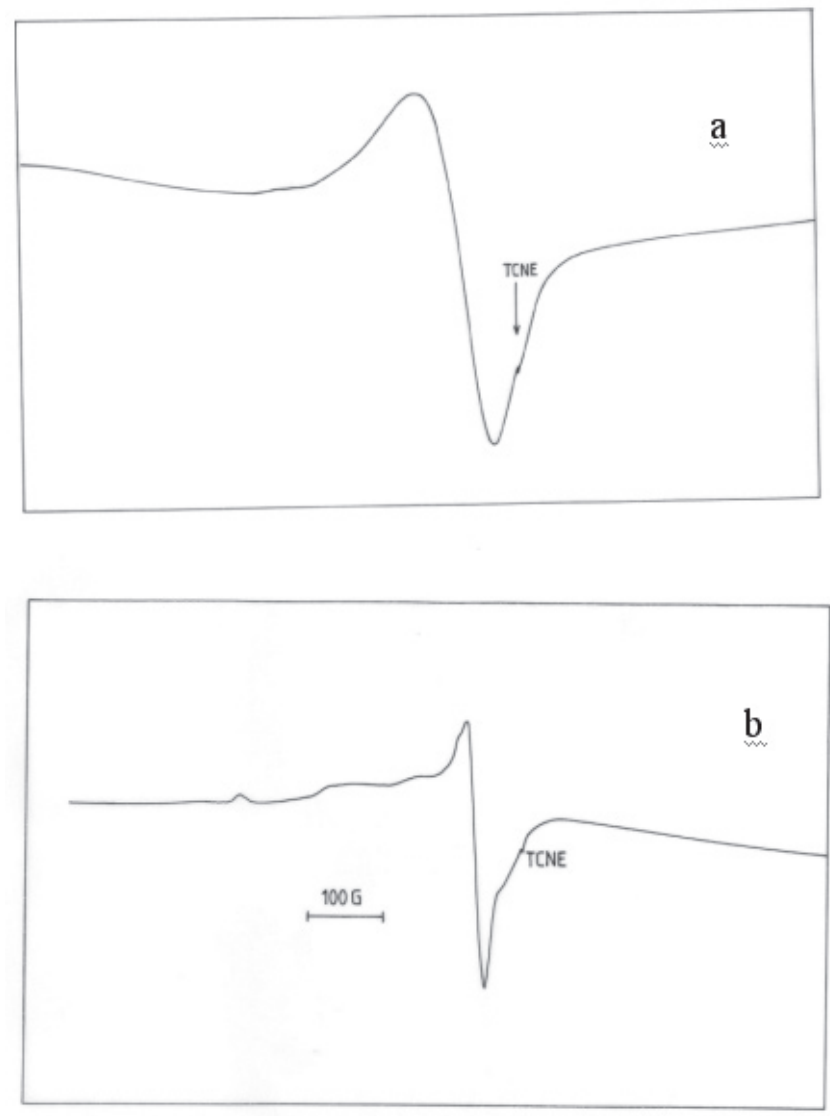

Figure 2. ESR spectra of the copper complex at $300 \mathrm{~K}$ (a) and $77 \mathrm{~K}$ (b)

If $\mathrm{G}>4.0$, the local tetragonal axes are aligned parallel or only slightly misaligned. If $\mathrm{G}<4.0$, significant exchange coupling is present and the misalignment is appreciable. The observed value for the exchange interaction parameter for the copper complex $(\mathrm{G}=5.7)$ suggests that the local tetragonal axes are aligned parallel or slightly misaligned, and the unpaired electron is present in the $\mathrm{d}_{\mathrm{x}-\mathrm{y}}^{2}{ }^{2}$ orbital. This result also indicates that the exchange coupling effects are not operative in the present complex ${ }^{30}$

Based on the above spectral data, the following structure has been proposed. The predicted structure of the complex is given in Fig. 3.

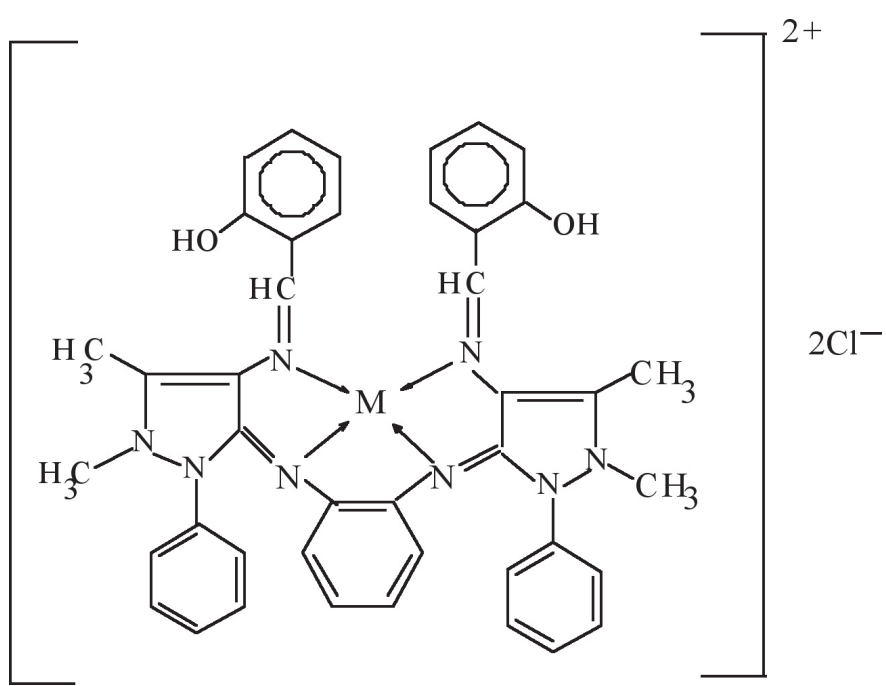

Figure 3. The proposed structure of the Schiff base complexes 


\section{Antimicrobial Activity}

For in vitro antimicrobial activity, the investigated compounds were tested against the bacteria Salmonella typhi, Staphylococcus aureus, Escherichia coli, and Bacillus subtilis and fungi Aspergillus niger, Aspergillus flavus and Rhizoctonia bataicola. The minimum inhibitory concentration (MIC) values of the investigated compounds are summarized in Table 3 and 4. From the tables, the observed MIC values indicate that most of the complexes have higher antimicrobial activity than the free ligand. Such increased activity of the metal chelates can be explained on the basis of chelation theory. On chelation, the polarity of the metal ion will be reduced to a greater extent due to the overlap of the ligand orbital and partial sharing of the positive charge of the metal ion with donor groups. Further, it increases the delocalization of $\pi$-electrons over the whole chelate ring and enhances the penetration of the complexes into lipid membranes and blocking of the metal binding sites in the enzymes of microorganisms. These complexes also disturb the respiration process of the cell and thus block the synthesis of proteins, which restricts further growth of the organism ${ }^{16}$.

Table 3. Antibacterial activity of the Schiff base ligand and its metal complexes (minimum inhibitory concentration x $10^{-2} \mathrm{M}$ )

\begin{tabular}{|c|c|c|c|c|}
\hline Compound & S.typhi & S. aureus & E. coli & $\begin{array}{c}\text { B. } \\
\text { subtilis }\end{array}$ \\
\hline $\mathrm{L}$ & 5.6 & 5.7 & 5.6 & 5.8 \\
\hline$[\mathrm{CuL}] \mathrm{Cl}_{2}$ & 4.2 & 4.0 & 4.3 & 4.5 \\
\hline$[\mathrm{CoL}] \mathrm{Cl}_{2}$ & 4.4 & 4.8 & 4.6 & 4.7 \\
\hline$\left[\mathrm{NiL}_{\mathrm{C}}{ }_{2}\right.$ & 4.5 & 4.6 & 4.3 & 4.5 \\
\hline$[\mathrm{ZnL}] \mathrm{Cl}_{2}$ & 4.7 & 4.7 & 4.6 & 4.6 \\
\hline
\end{tabular}

Table 4. Antifungal activity of the Schiff base ligand and its metal complexes (minimum inhibitory concentration $\times 10^{-2} \mathrm{M}$ )

\begin{tabular}{|c|c|c|c|}
\hline Compound & A. niger & A. flavus & R. bataicola \\
\hline $\mathrm{L}$ & 6.9 & 7.1 & 6.8 \\
\hline$[\mathrm{CuL}] \mathrm{Cl}_{2}$ & 5.3 & 5.6 & 5.8 \\
\hline$[\mathrm{CoL}] \mathrm{Cl}_{2}$ & 5.5 & 5.7 & 5.3 \\
\hline$\left[\mathrm{NiL}_{\mathrm{C}} \mathrm{Cl}_{2}\right.$ & 5.2 & 5.4 & 5.5 \\
\hline$[\mathrm{ZnL}] \mathrm{Cl}_{2}$ & 5.6 & 5.6 & 5.6 \\
\hline
\end{tabular}

\section{DNA studies}

The cleavage efficiency of the complexes compared to that of the control is due to their efficient DNA-binding ability. The metal complexes were able to convert super coiled DNA into open circular DNA. The general oxidative mechanisms proposed account of DNA cleavage by hydroxyl radicals via. abstraction of a hydrogen atom from sugar units and predict the release of specific residues arising from transformed sugars, depending on the position from which the hydrogen atom is removed ${ }^{31}$. The cleavage is inhibited by the free radical scavengers implying that hydroxyl radical or peroxy derivatives mediate the cleavage reaction. The reaction is modulated by metallocomplexes bound hydroxyl radical or a peroxo species generated from the co-reactant $\mathrm{H}_{2} \mathrm{O}_{2}$.

In the present study, the CT-DNA gel electrophoresis experiment was conducted at $35^{\circ} \mathrm{C}$ using our synthesized complexes in the presence of $\mathrm{H}_{2} \mathrm{O}_{2}$ as an oxidant. As can be seen from the results in Fig. 4, at very low concentration, only copper complex exhibits nuclease activity in the presence of $\mathrm{H}_{2} \mathrm{O}_{2}$. Control experiment using DNA alone (lane 1) does not show any significant cleavage of CT-DNA even on longer exposure time. From the observed results, we conclude that the copper complex (lane 2) cleaves DNA as compared to control DNA while other complexes (lane 3-5) do not cleave DNA in the presence of
$\mathrm{H}_{2} \mathrm{O}_{2}$. Further, the presence of a smear in the gel diagram indicates the presence of radical cleavage ${ }^{32}$.

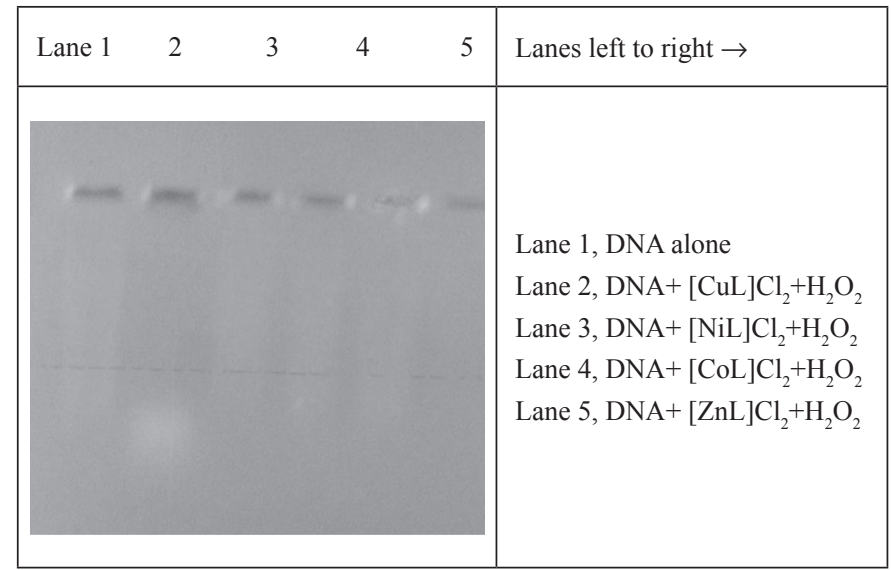

Figure 4. Changes in the agarose gel electrophoretic pattern of CT DNA induced by $\mathrm{H}_{2} \mathrm{O}_{2}$ and metal complexes

\section{CONCLUSIONS}

In this paper, coordination chemistry of a Schiff base ligand, obtained from the reaction of 4-aminoantipyrine, salicylaldehyde and $o$-phenylenediamine is described. $\mathrm{Cu}(\mathrm{II}), \mathrm{Co}(\mathrm{II}), \mathrm{Ni}(\mathrm{II})$ and $\mathrm{Zn}(\mathrm{II})$ complexes have been synthesized using the above Schiff base ligand and characterized by spectral and analytical data. Based on these data, a square-planar geometry has been assigned to the complexes. The metal complexes have higher antimicrobial activity than the ligand. The interaction of these complexes with CT-DNA was investigated by gel electrophoresis. From the observation, copper complex cleaves DNA as compared to control DNA and other complexes in the presence of $\mathrm{H}_{2} \mathrm{O}_{2}$.

\section{ACKNOWLEDGMENTS}

The authors express their sincere thanks to the Managing Board, Principal and Head of the Department of Chemistry, VHNSN College, Virudhunagar for their constant encouragement and providing research facilities. JD thanks the Tamilnadu Government for financial assistance.

\section{REFERENCES}

1. D.S. Sigman, D.R. Graham, V. D. Aaurora, J. Biol. Chem., 254, 1269 (1979)

2. V.M. Downey, B.R. Que, A.G. So, Biochem. Biophys. Res. Commun., 93, $264(1980)$

3. E.L. Marshall, D.R. Graham, K.A. Reith, Biochemistry, 20, 224 (1981)

4. H. Sigel, A. Sigel, Eds., Metal ions in biological systems, vols 26-32, New York: Marcel Dekker, 2000.

5. I. Helleman, C.C. Stock, J. Biol. Chem., 125, 771 (1983)

6. Z.S. Yang, Y.C. Wang, Z.C. Zhao, Anal. Sci., 20, 1127 (2004)

7. M. Palaniandavar, S. Ramakrishnan, J. Chem. Sci., 117, 179 (2005)

8. R. Pradhan, A.M. Thomas, A. Mukherjee, S. Dhar, M. Nethaji, A.R. Chakravarty. Indian J. Chem., 44A, 18 (2005)

9. T. Hitoshi, N. Tamao, A. Hideyyki, F. Manabu, M. Takayuki, Polyhedron, 16, 3787 (1997)

10. N. Raman, J.J. Raja, J. Joseph, J.D. Raja, J. Chil. Chem. Soc., 52, 1099 (2007)

11. Y.K. Choi, K.H. Chjo, S.M. Park, N. Doddapaneni, J. Electrochem. Soc., 142, 4107 (1995)

12. B. Katia, L. Simon, R. Anne, C. Gerard, D. Francoise, M. Bernard, Inorg. Chem., 35, 387 (1996)

13. N.Dharmaraj, P.Viswanathamurthi, K. Natarajan, Transition Met. Chem., 26, 105 (2001)

14. R.K. Agarwal, P. Garge, H. Agarwal, J. Chandra, Synth. React. Inorg. MetOrg. Chem., 27, 251 (1997)

15. L. Singh, N. Tyagi, N.P. Dhaka, S.K. Sindhu, Asian J. Chem. 11, 503 (1999) 
16. A. Kriza, A. Reiss, S. Florea, T. Caproiu, J. Indian Chem. Soc., 77, 207 (2000)

17. N. Raman, A. Kulandaisamy, K. Jeyasubramanian, Polish J. Chem., 76, 1085 (2002)

18. M.F. Iskander, L. Ei-Syed, K.Z. Ismail, Transition Met. Chem., 4, 225 (1979)

19. N. Raman, JDRaja, A. Sakthivel, J, Chem, Sci., 119. 303 (2007)

20. M. Thomas, M.K.M. Nair, R.K. Radhakrishan, Synth. React. Inorg. Met.Org. Chem., 25, 471 (1995)

21. K. Nakamoto, Infrared and Raman Spectra of Inorganic and Coordination Compounds, 3rd edn, New York: Wiley, 1997.

22. M.F. Iskander, L. Ei-Syed, K.Z. Ismail, Transition Met. Chem., 4, 225 (1979)

23. M. Thankamony, K. Mohanan, Indian J. Chem., 46A, 249 (2007)

24. DUWarad, CD Satish, DHKulkarni, CSBajgur, Indian J. Chem., 39A, 415 (200)
25. R.M. Kadam, M.D. Sastry, M.K. Bhide, S.A. Chavan, J.V. Yakhmi, O. Khan, Chem. Phys Lett., 281, 292 (1997)

26. M. Base, K. Ohta, Y. Babu, M.D. Sastry, Chem. Phys. Lett., 324, 330 (2000)

27. K.K. Ray, G.B. Kaufiman, Inorg. Chim. Acta, 173, 207 (1990)

28. K. Jeyasubramanian, S.A. Samath, S. Thambidurai, R. Murugesan, S.K. Ramalingam, Transition Met. Chem., 20, 76 (1996)

29. A.M.F. Benial, V. Ramakrishnan, R. Murugesan, Spectrochim. Acta, 56(A), 2775 (2000)

30. L.J. Boucher, E.C. Tyanan, T.F. Yen, Electron Spin Resonance of Metal Chelates, New York: Plenum press, 1969

31. N. Raman, J. Joseph, K. Rajasekaran, Polish. J. Chem., 81, 149 (2007)

32. A.M. Thomas, A.D. Naik, M. Nethaji, A.R. Chakravarty, Indian J. Chem., 43A, 691 (2004) 